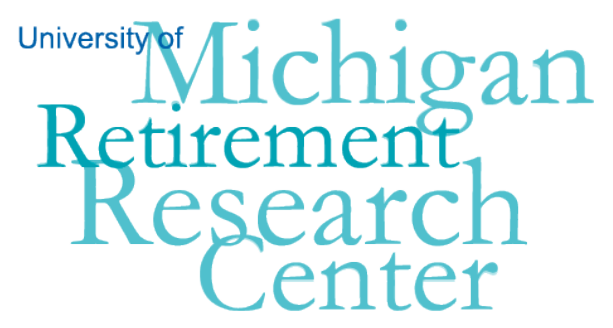

Working Paper WP 2013-283

\title{
Estimates of the Potential Insurance Value of Disability Insurance for Individuals with Mental Health Impairments
}

John Bound, Kyle J. Caswell and Timothy Waidmann

\begin{tabular}{|l|l|}
\hline $\mathrm{M}$ & $\mathrm{R}$ \\
\hline $\mathrm{R}$ & $\mathrm{C}$ \\
\hline
\end{tabular}

Project \#: UM12-15 



\title{
Estimates of the Potential Insurance Value of Disability Insurance for Individuals with Mental Health Impairments
}

\author{
John Bound \\ University of Michigan \\ Kyle J. Caswell \\ Urban Institute \\ Timothy Waidmann \\ Urban Institute
}

August 2013
Michigan Retirement Research Center
University of Michigan
P.O. Box 1248
Ann Arbor, MI 48104
www.mrrc.isr.umich.edu

(734) 615-0422

\section{Acknowledgements}

This work was supported by a grant from the Social Security Administration through the Michigan Retirement Research Center (Grant \# 5 RRC08098401-04-00). The findings and conclusions expressed are solely those of the author and do not represent the views of the Social Security Administration, any agency of the Federal government, or the Michigan Retirement Research Center. 


\title{
Estimates of the Potential Insurance Value of Disability Insurance for Individuals with Mental Health Impairments
}

\begin{abstract}
Since the mid-1980s there has been dramatic growth in the number and fraction of DI and SSI beneficiaries with mental illness. With longer life expectancies and younger ages of disability onset than beneficiaries with physical impairments, their growth exerts added fiscal pressure on the programs. While not specifically focused on mental illness, fears of an increase in the duration (and thus prevalence) of disability claims that may result from this demographic shift have generated calls to tighten eligibility rules again. Using data from the Health and Retirement Study linked to SSA administrative records, we created statistically matched control groups of non-beneficiaries with severe mental illness. We then estimated the earnings, income, and health insurance coverage among rejected DI/SSI applicants with mental illness who have characteristics comparable to persons awarded benefits on the basis of mental impairments. We found that even after controlling for health and demographic characteristics, DI beneficiaries were substantially worse off than rejected applicants in terms of wealth and income. While these rejected applicants with mental illness were worse off than those with physical impairments, our findings suggests that the programs successfully select applicants with the greatest income needs, and that retrenchment could result in significant hardship.
\end{abstract}

\section{Citation}

Bound, John, Kyle J. Caswell and Timothy Waidmann (2013). "Estimates of the Potential Insurance Value of Disability Insurance for Individuals with Mental Health Impairments." Michigan Retirement Research Center (MRRC) Working Paper, WP 2013-283. http://www.mrrc.isr.umich.edu/publications/papers/pdf/wp283.pdf 


\title{
Estimates of the Potential Insurance Value of Disability Insurance for Individuals with Mental Health Impairments
}

\author{
John Bound, Kyle J. Caswell, Timothy Waidmann
}

\section{Introduction}

Since the mid-1980s there has been dramatic growth in the number and fraction of Social Security Disability Insurance (DI) and Supplemental Security Income (SSI) beneficiaries with mental illness (Stapleton et al., 1998). Both the general rate of growth in DI and SSI rolls as well as the changing composition of beneficiaries has been a source of concern among some policy makers. Because of their younger age and better physical health, this new group of beneficiaries will collect benefits for a longer period of time than their predecessors in the program. While it is conceivable that scientific advances and expanded use of pharmacological treatments for mental illnesses might reduce their disabling effects, recent empirical analysis of the work-disincentive effects of DI has found relatively small work disincentive effects for this group. Using recent data on DI applicants, Maestas et al. (2010) estimated that among those applying with mental disabilities, the effect of being awarded benefits for those at the margin of working at all during the year was just $21 \%$. While not reported by type of condition, their estimates for all applicants suggest that a majority of those who would otherwise work would not earn enough to disqualify them from benefits. Indeed other researchers have found that earnings prospects for this population are not great. Using detailed data on mental health disorders the National Comorbidity Survey, Jayakody, Danziger \& Kessler (1998) found that early onset of these disorders resulted in lower educational attainment, and reduced rates of marriage and employment for men. More recent work (Kessler et al 2008) has found substantial earnings loss for those with serious mental illness.

This paper examines data on persons with mental illness to estimate the insurance value of the DI program for this population. That is, in the absence of disability benefits, what are the likely economic conditions facing those with severe mental illness? Using survey data from the Health and Retirement Study and Social Security Administration data linked to respondents, we examine the economic wellbeing of DI/SSI beneficiaries with mental illness compared to those with similar mental illness profiles not receiving benefits. Two sets of non-beneficiaries with 
mental illness will be used for comparison - those who had applied for benefits but were rejected, and those who for whatever reason chose not to apply, but were observationally equivalent to those who were awarded benefits.

\section{Data}

Health \& Retirement Study (HRS). The HRS is a longitudinal survey of a nationally representative sample of people over age 50 in the United States, which has been conducted since 1992. The HRS is sponsored by the National Institute of Aging and conducted by the University of Michigan. The sample is interviewed approximately every 2 years to obtain detailed information on health, income, wealth, living arrangements, insurance coverage, and work status of respondents and their spouses.

Social Security Administration Data. Several sources of administrative data from the Social Security Administration (SSA) were linked with the HRS for this work. Administrative data supplement the HRS by identifying whether respondents received DI or SSI benefits at the time of interview, and among beneficiaries, whether the basis of eligibility was a mental illness diagnosis. The data are also used to identify whether respondents not receiving DI/SSI had ever applied for benefits and, if so, the status of the application(s) at the time of interview (i.e., rejected, pending). Using these files (discussed below), we focus only on primary beneficiaries whose initial benefits were based on disabled worker status (e.g., excluding spouses and children of disabled workers).

The first source of administrative data is the Master Beneficiary Record (MBR). The MBR is used by the SSA to determine Social Security benefit payments for beneficiaries covered by the Old Age, Survivors and Disability Insurance (OASDI) program (Panis et al., 2000). We use two of the respondent cross-year benefits files (version 3.1) derived from the MBR for use with the HRS, covering benefits from January 1962 through December 2008. The section on the "primary beneficiary and other insured" is used to identify HRS respondents who ever applied for benefits, whose initial benefits were disabled worker benefits, and whether the (primary or secondary) disability diagnosis was a mental illness diagnosis. We then used the Ledger Account File (LAF) section, which includes monthly payment status information. We align information from the LAF with HRS respondents' month and year of interview to determine of benefits were 
active at the month of interview. Finally, among those that applied at some point before the interview, but do not receive benefits, we determine whether the application was rejected or pending.

The Supplemental Security Record (SSR) file contains records on all individual who ever applied for Title XVI Supplemental Security Income (SSI). We use SSR data constructed for use with the HRS, covering benefits from January 1974 through December 2003. This information is linked with the HRS to determine if respondents received SSI benefits at the time of interview. Among those that applied, but did not receive benefits, we determine the status of the application. Using this file we also identify whether the respondent was awarded SSI based on a mental illness diagnosis.

Master Earnings File (MEF) is the primary data source on earnings data for the SSA, which is mostly constructed from W-2 tax records. We use this data to identify all HRS respondents who not only gave permission to link their HRS data to SSA records, but also to find individuals who had matching SSA data.

HRS-SSA Linked Subsample. In this work, we limit the HRS sample to wave four respondents only. There are several reasons for this decision. First, the administrative data on SSI benefits was current through December 2003, which is well after the last wave four interview (March 1999), yet not current enough for wave seven interviews and beyond. Second, at wave four the AHEAD sample was merged with the HRS, and the war baby and CODA cohorts were added. This allowed us to increase our sample size. Finally, we could not use wave one because the question on mental health (CESD8), which is important for our methodology (discussed below), was not administered in the same way as waves two and beyond.

Using the wave four data, we study a subset of respondents. First, we restrict the data to respondents aged 50 to 64 with positive survey weights. This age range allows us to study respondents who work and have earnings income, compared with older respondents who are more likely retired. ${ }^{1}$ Second, we limit the subsample to respondents that gave permission to link their household survey responses to administrative records and had matching Social Security earnings data.

\footnotetext{
${ }^{1}$ Individuals with a survey weight equal to zero are those living in a nursing home, which we also excluded here.
} 
At wave four there were 21,384 respondents, from all cohorts. Of these, 11,756 respondents were out of the age range or had a survey weight equal to zero (restriction 1), and an additional 1,668 respondents did not have matching SSA earnings records (restriction 2). The final subsample includes 7,960 respondents. ${ }^{2}$ Among these 7,690 HRS respondents (table 1) 361 received DI/SSI benefits (column 1), of which a quarter (90 total) were diagnosed with a mental illness as the basis for their disability benefits. Of the remaining 7,329 respondents who did not receive benefits, 7,062 never applied, and 267 applied and were either were rejected or the outcome was uncertain (applied and not rejected, but not receiving benefits at time of interview).

Respondents with self-reported evidence of mental illness are important for the propensity score reweighting methods (discussed below), and are identified in table 1, column 2 . Using the HRS self-reported data, we define "mental illness" as 1) having ever been diagnosed with psychiatric problems, or 2) scoring five or higher on the CESD8, or 3) receiving DI/SSI based on a mental illness diagnosis. A total of 1,781 respondents met this criteria: 317 receive DI/SSI, 1,360 never applied, and 104 applied but were rejected or have not received a determination on their application.

Table 2 reports summary statistics on the entire subsample (column 1), as well as the subgroups of interest (columns 2-7). Among all respondents (column 1) the average CESD8 score equals 1.5 , and 15.5 percent report that they were ever diagnosed with psychiatric problems. Approximately 23 percent report "fair" or "poor" health status, and about the same proportion indicate that they have a health problem that limits their ability to work. Less than half are men (45.9 percent), most are white, non-Hispanic (85.1 percent) and married (70.7 percent).

Compared with the entire subsample, DI/SSI beneficiaries predictably reported much poorer mental health (column 2). On average these DI/SSI beneficiaries scored 3.9 on the CESD8, and 83.1 percent reported that they were ever diagnosed with a psychiatric problem. Additionally, they have a higher incidence of all other health conditions reported (high blood

\footnotetext{
${ }^{2}$ 6,414 were original HRS respondents, 1,492 belong to the war babies cohort, 27 belong to AHEAD, 25 are HRS/AHEAD overlap respondents, and 2 belong to the CODA cohort.
} 
pressure, diabetes, cancer, lung disease, stroke, arthritis, and obesity). And nearly all the DI/SSI beneficiaries diagnosed with mental illness reported that they have health problems that limit their ability to work ( 95.3 percent). They are also less likely male (36.3 percent) or married (42.1 percent).

\section{Methods}

Propensity score reweighting methods are used to construct statistically similar comparison groups to study differences in economic outcomes between DI/SSI beneficiaries and nonbeneficiaries (Barsky et al., 2002). We estimate latent models of DI/SSI eligibility to obtain propensity score estimates of DI/SSI eligibility. The dependent variable in the logit models identify DI/SSI enrollment using administrative data. Independent variables, reported in table 2, include mental health (CESD score, psychiatric problems), physical health (high blood pressure, diabetes, cancer, lung disease, heart attack/disease, stroke, arthritis, and obese), self-reported health status ("fair" or "poor"), and an indicator for whether the respondent has a health problem that limits their ability to work. Additional controls include age, sex, race/ethnicity, educational attainment, marital status, and spousal DI/SSI eligibility status. Four separate models are estimated for four different pairwise comparisons. Specifically, the four pairs are defined as follows (and correspond to columns 2-7 in table 2):

1. Group 1: Receiving DI/SSI and diagnosed with a mental illness; Group 2: Not receiving DI/SSI, never applied for DI/SSI, and report evidence of mental illness.

2. Group 1: Receiving DI/SSI and diagnosed with a mental illness; Group 2: Not receiving DI/SSI, applied and rejected or status uncertain, and reported evidence of mental illness.

3. Group 1: Receiving DI/SSI and not diagnosed with a mental illness (i.e., physical illness); Group 2: Not receiving DI/SSI, never applied for DI/SSI, and no evidence of mental illness.

4. Group 1: Receiving DI/SSI and not diagnosed with a mental illness (i.e., physical illness); 
Group 2: Not receiving DI/SSI, applied and rejected or status uncertain, and no evidence of mental illness.

Table 3 illustrates how the propensity score reweighting method changes the health and demographic characteristics of the comparison groups. For example, column 1 reports the characteristics of the DI/SSI beneficiaries with a mental illness diagnosis. Columns 2 and 3 report summary statistics, before and after reweighting, among non-beneficiaries with evidence of a mental illness who never applied for DI/SSI. In general, after reweighting the comparison group more closely resembles the DI/SSI beneficiary group. For example, from column 3 shows that the comparison group is more likely to have reported psychiatric problems, a health problem that limits work, and are less likely married. Columns 4 and 5 report another example of the reweighting, where the comparison group includes individuals who applied for DI/SSI and were rejected or have an unresolved application, and have self-reported evidence of mental illness.

\section{Results}

The following subsections report comparisons of income, wealth, and health insurance status across DI/SSI beneficiaries and non-beneficiaries. For non-beneficiaries we report values before and after the propensity score weighting adjustment. Finally, for each income/wealth comparison we report averages across groups, as well as the probability that income/wealth is greater than zero. Median values across groups are reported in appendix table A1.

Total household income per person. Table 4 reports results for average total household income per person, and the probability of positive household income. Each row reports comparisons before and after propensity score reweighting. The far left column identifies the type of DI/SSI beneficiaries in the comparison for a given row (Group 1). The type of non-beneficiaries are identified the adjacent column (Group 2). Results from table 4 generally show that average household income per person among DI/SSI beneficiaries is closer to non-beneficiaries who applied, but were either rejected or had an unresolved application at the time of interview, compared with those that never applied. Furthermore, most all respondents live in households that have some form of income.

The first row, for example, compares DI/SSI beneficiaries with a mental illness diagnosis with non-beneficiaries that never applied for DI/SSI, but reported evidence of a mental illness. 
Average household income per person among DI/SSI beneficiaries equals \$19,349 (Group 1), compared with $\$ 46,624$ among those who never applied (Group 2), which is a difference of $\$ 27,230$ per person. After reweighting, total household income per person among the never applied group decreases to $\$ 33,082$ (Group 2 reweighted), for a difference of $\$ 13,688$. That is, the reweighting decreases the difference by about half. Similarly, the second row compares the same DI/SSI beneficiaries with a mental illness diagnosis with respondents whose application was rejected or uncertain at the time of interview, and who reported evidence of a mental illness. This latter group had total household income per person equal to $\$ 22,256$, which is not statistically different from the DI/SSI beneficiary group. Reweighting (slightly) decreases total household income to $\$ 21,524$ per person, yet is not statistically different from the DI/SSI group.

The second and third rows compare DI/SSI beneficiaries without a mental illness diagnosis with non-beneficiaries that had no evidence of a mental illness. These results show that DI/SSI beneficiaries with a physical diagnosis have higher household income $(\$ 28,824)$ than their counterparts with a mental illness diagnosis (top two rows, \$19,394), yet lower than nonbeneficiaries with no evidence of a mental illness before reweighting (row 3, \$56,652) and after reweighting $(\$ 36,657)$. There is no statistical difference in average income between these DI/SSI beneficiaries and those who applied and where rejected, or whose application was still uncertain.

Earnings income. Table 5 reports results for earnings income on behalf of respondents (top panel), their spouse (middle panel), and total household earnings per person (bottom panel). Results for respondent earnings (top panel) show that very few DI/SSI beneficiaries had employment income compared with non-beneficiaries. Among DI/SSI beneficiaries with a mental illness diagnosis, only 6.6 percent reported any earnings income, compared with 57.5 percent of respondents that reported evidence of a mental illness, but never applied for DI/SSI. Similarly, 44.5 percent of non-beneficiaries with evidence of a mental illness, and whose SSI/DI application was rejected/uncertain at the time of interview, reported any earnings income. Results for average earnings reflect this, in that earnings for DI/SSI beneficiaries is much lower than non-beneficiaries.

Reweighting decreased the difference in average earnings between DI/SSI beneficiaries with a mental illness diagnosis and non-beneficiaries. However, reweighting did not eliminate 
the differences. Reweighting had the greatest impact on non-beneficiaries that never applied for DI/SSI, who had higher earnings to begin with.

Results for spouse earnings are reported in the middle panel of table 5. Respondents without a spouse are included in these statistics, and take a value equal to zero. Respondents with DI/SSI have greater spouse earnings, both in terms of average earnings and the proportion with any income, than own earnings (top panel), yet lower than non-beneficiary spouse income. For example, 23.3 percent of DI/SSI beneficiaries with a mental illness diagnosis have positive spouse income, compared with 38.9 percent of non-beneficiaries that never applied but have evidence of a mental illness. This difference in part reflects that DI/SSI beneficiaries are less likely married (see table 2). Similarly, average spouse income for these beneficiaries equals $\$ 9,446$, compared with $\$ 17,691$ for non-beneficiaries that never applied. Comparisons between DI/SSI beneficiaries with a mental illness and non-beneficiaries whose application was rejected/uncertain are not statistically different. Finally, differences in spouse income between DI/SSI beneficiaries with a mental illness and non-beneficiaries are not statistically significant after reweighting the non-beneficiary sample.

Spouse earnings is greater among respondents with DI/SSI and no mental illness diagnosis (i.e., physical disability), yet still lower than non-beneficiaries that never applied. 35.3 percent of these DI/SSI beneficiaries have a spouse with positive earnings income, compared with almost half (48.2 percent) of non-beneficiaries who never applied.

The bottom panel of table 5 reports results for total household earnings per person. For DI/SSI beneficiaries spouse earnings is a significant contribution to total earnings, yet it is still significantly lower than that for non-beneficiaries. Among beneficiaries with a mental illness, 30 percent have some household earnings, compared with 70.5 percent of non-beneficiaries that never applied but have evidence of a mental illness. As a result, average income among the $\mathrm{DI} / \mathrm{SSI}$ beneficiaries equals $\$ 5,190$ per person, compared with $\$ 24,159$ per person for the never applied group. Reweighting does decrease the difference in total earnings between beneficiaries and non-beneficiaries, however total earnings among the non-beneficiaries is always significantly greater. Results for DI/SSI beneficiaries without a mental illness and nonbeneficiaries are similar. 
Wealth. Table 6 reports results for net housing wealth of the primary residence (top panel), and net non-housing wealth (bottom panel). Half of DI/SSI recipients with a mental illness diagnosis report positive net housing wealth for their primary residence, compared with 84.2 percent of non-beneficiaries that never applied, yet reported evidence of a mental illness. Similarly, average housing wealth per person for DI/SSI beneficiaries equals $\$ 21,978$ per person, compared with $\$ 55,382$ per person among non-beneficiaries that never applied. Comparisons with nonbeneficiaries whose application was rejected/uncertain are not statistically significant. Reweighting decreases the difference in net housing wealth per person between beneficiaries with a mental illness diagnosis and non-beneficiaries who never applied and reported evidence of a mental illness-yet does not eliminate it.

The bottom panel of table 6 reports results for net non-housing wealth. Almost three quarters of DI/SSI beneficiaries with a mental illness diagnosis reported positive net non-housing wealth (72.9 percent). The rate is higher for non-beneficiaries that never applied, with evidence of a mental illness (84.2 percent). The never applied group also has much higher average net non-housing wealth per person $(\$ 133,362$ compared with $\$ 57,815)$. Net non-housing wealth among non-beneficiaries who applied for DI/SSI was not statistically different from beneficiaries with DI/SSI diagnosed with a mental illness. Reweighting decreased the difference in net nonhousing wealth between beneficiaries and non-beneficiaries that never applied such that they are not statistically different from each other.

Among DI/SSI beneficiaries without a mental health diagnosis, 85.1 percent reported positive net non-housing wealth. Almost all non-beneficiaries who never applied reported positive non-housing wealth (91.4 percent). Average net non-housing wealth was also much less for the beneficiaries compared with non-beneficiaries that never applied (\$77,253 and \$202,097, respectively). However, SSI/DI beneficiaries without a mental illness had greater net nonhousing wealth per person than respondents who applied, but whose application was rejected/uncertain at the time of interview (\$77,253 and $\$ 34,964$, respectively).

Health Insurance. Self-reported health insurance status by DI/SSI status is reported in Table 7. Most all DI/SSI beneficiaries report that they had health insurance (90.5 percent). Indeed, all of these respondents should have government health insurance. A much smaller proportion of nonbeneficiaries with evidence of mental illness reported health insurance: 66.9 percent of the never 
applied, and 53.1 percent of those whose application was rejected/uncertain at the time of interview. The reweighting adjustment increased the rate of insurance among the never applied comparison group, yet decreased it among the rejected/uncertain group.

Most DI/SSI beneficiaries without a mental illness diagnosis reported health insurance coverage (85.7 percent). Non-beneficiaries reported a lower rate of insurance: 69.6 percent among the never applied, and 59.3 percent among those who applied and were rejected or whose application was uncertain at the time of interview.

\section{Discussion}

The analyses presented above suggest that while federal and state Disability Insurance programs may not fully make up for income and wealth deficits experienced by persons with mental disabilities, they are an important source of support. This is clearest in rates of insurance coverage, where a DI or SSI award confers coverage by Medicare or Medicaid, respectively. Successful applicants have much higher rates of health insurance coverage than either nonapplicants or rejected applicants. The same is true of persons with or without mental illness. In terms of total household income, we find that for those without any indication of mental illness, the DI and SSI programs increase per capita household income of successful applicants above that of rejected applicants, but the same is not true for those with mental illness.

Further, contrary to what is commonly thought, those who apply for DI benefits on the basis of mental illness do not appear to be more "marginal" applicants. In fact, persons with mental illness who have been denied DI and SSI benefits are worse off than those rejected applicants not reporting any mental illness on nearly every measure of well-being, and successful applicants with mental illness are worse off than successful applicants with only physical disabilities.

Among those with mental illness, the fact that successful applicants appear worse off than observationally equivalent rejected applicants can be interpreted in several ways. One possibility is that the DI/SSI screening process is accurately discriminating between applicants on unobservable characteristics, selecting those with the most difficulty generating income. 


\section{References}

Barsky, R., J. Bound, K. Charles and J. Lupton, 2002. “Accounting for the Black-White Wealth Gap: A Nonparametric Approach.” Journal of the American Statistical Association 94 (459), 663-673.

Bound J, Waidmann T. (2010) "The Social Security Early Retirement Benefit as Safety Net" MRRC Working Paper 2010-240, October.

Jayakody R, Danziger S, Kessler, RC. (1998) "Early-onset psychiatric disorders and male socioeconomic status." Social Science Research, 27(4):371-387.

Kessler RC, Heeringa S, Lakoma MD, Petukhova M, Rupp AE, Schoenbaum M, Wang PS, Zaslavsky AM. (2008) "Individual and societal effects of mental disorders on earnings in the United States: results from the national comorbidity survey replication." American Journal of Psychiatry 165(6):703-11.

Maestas, N, Mullen K and Strand A. (2010) "Does Disability Insurance Receipt Discourage

Work? Using Examiner Assignment to Estimate Causal Effects of SSDI Receipt” MRRC

Working Paper 2010-241, December. (forthcoming American Economic Review)

Nelson, CB, Kessler, RC, and Mroczek, D (1998) Scoring the World Health Organization's Composite International Diagnostic Interview Short Form (CIDI-SF; v1.0 NOV98).

Panis, C., R. Euller, C. Grant, M. Bradley, C. Peterson, R. Hirscher, and P. Steinberg, 2000. “SSA Program Data User’s Manual.” RAND, Project Memorandum PM-973-SSA.

Stapleton DC, Coleman KA, Dietrich KA, and Livermore GA. (1998) "Econometric Analyses of DI and SSI Application and Award Growth.” In Kalman Rupp and David C. Stapleton (eds.), Growth in Disability Benefits: Explanations and Policy Implications. Kalamazoo, MI: W.E. Upjohn Institute for Employment Research, 31-92. 
Table 1. Number of 50-64 year old respondents at wave 4 with matched SSA income records and positive survey weights

\begin{tabular}{|c|c|c|c|c|c|c|}
\hline & \multicolumn{3}{|c|}{ Individuals } & \multicolumn{3}{|c|}{ Households } \\
\hline & $(1)$ & $(2)$ & $(3)$ & $(4)$ & $(5)$ & $(6)$ \\
\hline & All & $\begin{array}{l}\text { Mental } \\
\text { illness* }\end{array}$ & $\begin{array}{l}\text { No mental } \\
\text { illness* }\end{array}$ & All & $\begin{array}{l}\text { Mental } \\
\text { illness* }\end{array}$ & $\begin{array}{c}\text { No mental } \\
\text { illness* }\end{array}$ \\
\hline All & 7,960 & 1,781 & 6,179 & 5,948 & 1,677 & 4,814 \\
\hline Receiving DI/SSI at wave 4 & 631 & 317 & 314 & 605 & 310 & 305 \\
\hline Mental illness diagnosis (primary or secondary)** & 90 & 90 & 0 & 90 & 90 & 0 \\
\hline No mental illness diagnosis (primary or secondary) & 541 & 227 & 314 & 525 & 224 & 305 \\
\hline No DI/SSI & 7,329 & 1,464 & 5,865 & 5,572 & 1,400 & 4,611 \\
\hline Never applied & 7,062 & 1,360 & 5,702 & 5,384 & 1,301 & 4,492 \\
\hline Applied \& rejected or status uncertain & 267 & 104 & 163 & 261 & 104 & 160 \\
\hline Applied \& status uncertain & 69 & 21 & 48 & 68 & 21 & 47 \\
\hline
\end{tabular}

*Primary or secondary mental illness diagnosis identified from administrative data (DI/SSI) or previously diagnosed with psychiatric problems or CESD 8 Score $\geq 5$.

**Identified using administrative data as a primary or secondary diagnosis.

Source: Authors' calculations using the HRS linked with SSA administrative data. 
Table 2: Summary statistics, wave 4 respondents aged 50-64 with matched SSA income records and positive survey weights

\begin{tabular}{|c|c|c|c|c|c|c|c|}
\hline & $(1)$ & $(2)$ & $(3)$ & $(4)$ & $(5)$ & $(6)$ & $(7)$ \\
\hline & $\begin{array}{c}\text { All } \\
\text { respondents }\end{array}$ & $\begin{array}{c}\text { Receiving } \\
\text { DI/SSI } \\
\text { with mental } \\
\text { illness } \\
\text { diagnosis** }\end{array}$ & $\begin{array}{c}\text { Mental } \\
\text { illness* \& no } \\
\text { DI/SSI \& } \\
\text { never applied }\end{array}$ & $\begin{array}{c}\text { Mental } \\
\text { illness* \& } \\
\text { no DI/SSI \& } \\
\text { rejected or } \\
\text { status } \\
\text { uncertain }\end{array}$ & $\begin{array}{l}\text { No mental } \\
\text { illness* \& } \\
\text { receiving } \\
\text { DI/SSI }\end{array}$ & $\begin{array}{c}\text { No mental } \\
\text { illness* \& no } \\
\text { DI/SSI \& } \\
\text { never applied }\end{array}$ & $\begin{array}{l}\text { No mental } \\
\text { illness* \& no } \\
\text { DI/SSI \& } \\
\text { rejected or } \\
\text { status } \\
\text { uncertain }\end{array}$ \\
\hline $\mathrm{N}$ & 7,960 & 90 & 1,360 & 104 & 314 & 5,702 & 163 \\
\hline CESD (average, integer scale 0 to 8 ) & 1.5 & 3.9 & 3.6 & 4.1 & 1.5 & 0.9 & 1.3 \\
\hline Psychiatric problems & $15.5 \%$ & $83.1 \%$ & $70.1 \%$ & $72.5 \%$ & $0.0 \%$ & $0.0 \%$ & $0.0 \%$ \\
\hline High blood pressure & $39.0 \%$ & $55.2 \%$ & $45.5 \%$ & $65.7 \%$ & $54.6 \%$ & $34.8 \%$ & $50.8 \%$ \\
\hline Diabetes & $11.3 \%$ & $23.6 \%$ & $13.1 \%$ & $26.3 \%$ & $21.3 \%$ & $9.2 \%$ & $14.9 \%$ \\
\hline Cancer & $7.0 \%$ & $10.0 \%$ & $10.0 \%$ & $9.0 \%$ & $9.6 \%$ & $5.9 \%$ & $5.3 \%$ \\
\hline Lung disease & $6.9 \%$ & $17.7 \%$ & $12.2 \%$ & $19.8 \%$ & $13.6 \%$ & $4.4 \%$ & $10.5 \%$ \\
\hline Heart attack/disease & $13.4 \%$ & $35.2 \%$ & $17.6 \%$ & $20.5 \%$ & $32.4 \%$ & $10.0 \%$ & $15.6 \%$ \\
\hline Stroke & $2.8 \%$ & $9.0 \%$ & $3.6 \%$ & $5.4 \%$ & $11.4 \%$ & $1.8 \%$ & $0.8 \%$ \\
\hline Arthritis & $44.7 \%$ & $66.2 \%$ & $56.2 \%$ & $80.0 \%$ & $66.1 \%$ & $38.8 \%$ & $55.0 \%$ \\
\hline Obese $(\mathrm{BMI} \geq 30)$ & $29.4 \%$ & $41.8 \%$ & $31.6 \%$ & $47.7 \%$ & $42.4 \%$ & $27.0 \%$ & $43.0 \%$ \\
\hline "Fair" or "poor" health & $23.2 \%$ & $69.7 \%$ & $37.3 \%$ & $63.4 \%$ & $65.0 \%$ & $14.0 \%$ & $36.8 \%$ \\
\hline Health problems limit work & $23.1 \%$ & $95.3 \%$ & $34.7 \%$ & $77.1 \%$ & $83.5 \%$ & $12.7 \%$ & $33.6 \%$ \\
\hline Age & 56.8 & 56.5 & 56.7 & 57.2 & 57.0 & 56.7 & 56.5 \\
\hline Sex $=$ Male & $45.9 \%$ & $36.3 \%$ & $32.5 \%$ & $31.6 \%$ & $58.1 \%$ & $48.9 \%$ & $48.8 \%$ \\
\hline White, non-Hispanic & $81.5 \%$ & $70.1 \%$ & $78.6 \%$ & $65.7 \%$ & $71.7 \%$ & $84.0 \%$ & $65.9 \%$ \\
\hline Black, non-Hispanic & $9.2 \%$ & $16.8 \%$ & $8.6 \%$ & $22.4 \%$ & $17.8 \%$ & $8.1 \%$ & $18.7 \%$ \\
\hline Other, non-Hispanic & $2.3 \%$ & $4.1 \%$ & $2.1 \%$ & $2.0 \%$ & $2.9 \%$ & $2.2 \%$ & $2.2 \%$ \\
\hline Hispanic & $7.1 \%$ & $8.9 \%$ & $10.7 \%$ & $9.9 \%$ & $7.6 \%$ & $5.7 \%$ & $13.3 \%$ \\
\hline Less than high school & $18.0 \%$ & $23.1 \%$ & $25.5 \%$ & $38.7 \%$ & $32.9 \%$ & $13.7 \%$ & $34.8 \%$ \\
\hline High school equivalent \& less than Bachelor's & $59.6 \%$ & $65.7 \%$ & $57.0 \%$ & $58.9 \%$ & $55.6 \%$ & $60.8 \%$ & $57.8 \%$ \\
\hline College graduate & $22.3 \%$ & $11.3 \%$ & $17.4 \%$ & $2.4 \%$ & $11.5 \%$ & $25.5 \%$ & $7.4 \%$ \\
\hline Married & $70.7 \%$ & $42.1 \%$ & $59.3 \%$ & $51.0 \%$ & $65.2 \%$ & $75.1 \%$ & $62.4 \%$ \\
\hline Spouse receiving DI/SSI & $3.8 \%$ & $8.9 \%$ & $4.3 \%$ & $7.7 \%$ & $8.9 \%$ & $3.0 \%$ & $8.1 \%$ \\
\hline
\end{tabular}

*Primary or secondary mental illness diagnosis identified from administrative data (DI/SSI) or previously diagnosed with psychiatric problems or CESD 8

Score $\geq 5$.

**Identified using administrative data as a primary or secondary diagnosis.

Source: Authors' calculations using the HRS linked with SSA administrative data. 


\begin{tabular}{|c|c|c|c|c|c|}
\hline & \multirow[b]{2}{*}{$\begin{array}{c}(1) \\
\text { Receiving } \\
\text { DI/SSI } \\
\text { with mental } \\
\text { illness } \\
\text { diagnosis** }\end{array}$} & \multicolumn{2}{|c|}{ (3) } & \multicolumn{2}{|c|}{$(4) \quad(5)$} \\
\hline & & \multicolumn{2}{|c|}{$\begin{array}{l}\text { Mental illness* \& } \\
\text { no DI/SSI \& } \\
\text { never applied }\end{array}$} & \multicolumn{2}{|c|}{$\begin{array}{c}\text { Mental illness* \& } \\
\text { no DI/SSI \& } \\
\text { rejected/status uncertain }\end{array}$} \\
\hline & & Raw & Reweighted & Raw & Reweighted \\
\hline $\mathrm{N}$ & 90 & \multicolumn{2}{|c|}{1,360} & \multicolumn{2}{|c|}{104} \\
\hline CESD (average, integer scale 0 to 8 ) & 4.0 & 3.6 & 3.9 & 4.1 & 3.7 \\
\hline Psychiatric problems & $83.1 \%$ & $70.1 \%$ & $82.2 \%$ & $72.5 \%$ & $85.6 \%$ \\
\hline High blood pressure & $55.2 \%$ & $45.5 \%$ & $54.0 \%$ & $65.7 \%$ & $60.1 \%$ \\
\hline Diabetes & $23.6 \%$ & $13.1 \%$ & $22.6 \%$ & $26.3 \%$ & $22.7 \%$ \\
\hline Cancer & $10.0 \%$ & $10.0 \%$ & $10.1 \%$ & $9.0 \%$ & $8.8 \%$ \\
\hline Lung disease & $17.7 \%$ & $12.2 \%$ & $17.3 \%$ & $19.8 \%$ & $24.0 \%$ \\
\hline Heart attack/disease & $35.2 \%$ & $17.6 \%$ & $35.9 \%$ & $20.5 \%$ & $39.6 \%$ \\
\hline Stroke & $9.0 \%$ & $3.6 \%$ & $8.9 \%$ & $5.4 \%$ & $7.2 \%$ \\
\hline Arthritis & $66.2 \%$ & $56.2 \%$ & $65.9 \%$ & $80.0 \%$ & $69.6 \%$ \\
\hline Obese $(\mathrm{BMI} \geq 30)$ & $41.8 \%$ & $31.6 \%$ & $40.8 \%$ & $47.7 \%$ & $42.3 \%$ \\
\hline "Fair" or "poor" health & $69.7 \%$ & $37.3 \%$ & $69.4 \%$ & $63.4 \%$ & $68.8 \%$ \\
\hline Health problems limit work & $95.3 \%$ & $34.7 \%$ & $95.3 \%$ & $77.1 \%$ & $94.6 \%$ \\
\hline Age & 56.5 & 56.7 & 56.6 & 57.2 & 56.7 \\
\hline Sex $=$ Male & $36.3 \%$ & $32.5 \%$ & $30.5 \%$ & $31.6 \%$ & $30.3 \%$ \\
\hline White, non-Hispanic & $70.1 \%$ & $78.6 \%$ & $70.0 \%$ & $65.7 \%$ & $66.1 \%$ \\
\hline Black, non-Hispanic & $16.8 \%$ & $8.6 \%$ & $15.8 \%$ & $22.4 \%$ & $24.1 \%$ \\
\hline Other, non-Hispanic & $4.1 \%$ & $2.1 \%$ & $2.7 \%$ & $2.0 \%$ & $1.9 \%$ \\
\hline Hispanic & $8.9 \%$ & $10.7 \%$ & $11.5 \%$ & $9.9 \%$ & $7.9 \%$ \\
\hline Less than high school & $23.1 \%$ & $25.5 \%$ & $23.2 \%$ & $38.7 \%$ & $28.0 \%$ \\
\hline High school equivalent \& less than Bachelor's & $65.7 \%$ & $57.0 \%$ & $65.8 \%$ & $58.9 \%$ & $64.9 \%$ \\
\hline College graduate & $11.3 \%$ & $17.4 \%$ & $11.0 \%$ & $2.4 \%$ & $7.2 \%$ \\
\hline Married & $42.1 \%$ & $59.3 \%$ & $42.4 \%$ & $51.0 \%$ & $40.6 \%$ \\
\hline Spouse receiving DI/SSI & $8.9 \%$ & $4.3 \%$ & $9.2 \%$ & $7.7 \%$ & $5.7 \%$ \\
\hline
\end{tabular}

*Primary or secondary mental illness diagnosis identified from administrative data (DI/SSI) or previously diagnosed with psychiatric problems or CESD 8 Score $\geq 5$.

**Identified using administrative data as a primary or secondary diagnosis.

Source: Authors' calculations using the HRS linked with SSA administrative data. 


\begin{tabular}{|c|c|c|c|c|c|c|c|c|c|c|c|}
\hline \multirow[b]{3}{*}{$\begin{array}{c}\text { Group } 1 \\
\text { DI/SSI beneficiaries }\end{array}$} & \multirow[b]{3}{*}{$\begin{array}{c}\text { Group } 2 \\
\text { Non-DI/SSI beneficiaries }\end{array}$} & \multicolumn{10}{|c|}{ Household income per person } \\
\hline & & \multicolumn{5}{|c|}{ Average } & \multicolumn{5}{|c|}{ Greater than zero } \\
\hline & & Group 1 & Group 2 & $p$-val & $\begin{array}{l}\text { Group 2 } \\
\text { reweighted }\end{array}$ & $p$-val & Group 1 & Group 2 & $p$-val & $\begin{array}{c}\text { Group 2 } \\
\text { reweighted }\end{array}$ & $p$-val \\
\hline With mental illness diagnosis** & Never applied for DI/SSI, with mental illness* & $\$ 19,394$ & $\$ 46,624$ & 0.000 & $\$ 33,082$ & 0.000 & $99.7 \%$ & $98.7 \%$ & 0.040 & $98.2 \%$ & 0.154 \\
\hline With mental illness diagnosis** & Application rejected/uncertain, with mental illness* & $\$ 19,394$ & $\$ 22,256$ & 0.355 & $\$ 21,524$ & 0.565 & $99.7 \%$ & $97.4 \%$ & 0.170 & $98.3 \%$ & 0.237 \\
\hline Without mental illness diagnosis** & Never applied for DI/SSI \& no mental illness* & $\$ 28,824$ & $\$ 56,652$ & 0.000 & $\$ 36,657$ & 0.023 & $98.6 \%$ & $99.3 \%$ & 0.521 & $99.3 \%$ & 0.557 \\
\hline Without mental illness diagnosis** & Application rejected/uncertain \& no mental illness* & $\$ 28,824$ & $\$ 29,319$ & 0.882 & $\$ 25,265$ & 0.291 & $98.6 \%$ & $97.7 \%$ & 0.514 & $92.1 \%$ & 0.138 \\
\hline
\end{tabular}

*Primary or secondary mental illness diagnosis identified from administrative data (DI/SSI) or previously diagnosed with psychiatric problems or CESD 8 Score $\geq 5$.

**Identified using administrative data as a primary or secondary diagnosis.

$p$-val corresponds to the null hypothesis that the statistic in column Group 1 equals Group 2 (or Group 1 equals Group 2 reweighted) for a given row.

Source: Authors' calculations using the HRS linked with SSA administrative data. 
Table 5: Earnings income among DI/SSI beneficiaries compared with non-beneficiaries

\begin{tabular}{|c|c|c|c|c|c|c|c|c|c|c|}
\hline \multirow[b]{3}{*}{$\begin{array}{c}\text { Group } 1 \\
\text { DI/SSI beneficiaries }\end{array}$} & \multirow[b]{3}{*}{$\begin{array}{c}\text { Group } 2 \\
\text { Non-DI/SSI beneficiaries }\end{array}$} & \multicolumn{9}{|c|}{ Own earnings } \\
\hline & & \multicolumn{5}{|c|}{ Average } & \multicolumn{4}{|c|}{ Greater than zero } \\
\hline & & \multicolumn{5}{|c|}{ reweighted } & \multicolumn{4}{|c|}{ reweighted } \\
\hline With mental illness diagnosis** & Never applied for DI/SSI, with mental illness* & $\$ 549$ & $\$ 23,263$ & 0.000 & $\$ 10,252$ & 0.000 & $6.6 \%$ & $57.5 \% \quad 0.000$ & $35.9 \%$ & 0.000 \\
\hline With mental illness diagnosis** & Application rejected/uncertain, with mental illness* & $\$ 549$ & $\$ 9,836$ & 0.000 & $\$ 7,537$ & 0.002 & $6.6 \%$ & $44.5 \% \quad 0.000$ & $42.0 \%$ & 0.000 \\
\hline Without mental illness diagnosis** & Never applied for DI/SSI \& no mental illness* & $\$ 5,773$ & $\$ 37,628$ & 0.000 & $\$ 16,385$ & 0.000 & $18.9 \%$ & $69.3 \% \quad 0.000$ & $40.8 \%$ & 0.000 \\
\hline \multirow[t]{3}{*}{ Without mental illness diagnosis** } & Application rejected/uncertain \& no mental illness* & $\$ 5,773$ & $\$ 21,017$ & 0.000 & $\$ 16,707$ & 0.003 & $18.9 \%$ & $67.2 \% \quad 0.000$ & $51.5 \%$ & 0.000 \\
\hline & & \multicolumn{9}{|c|}{ Spouse earnings (equals $\$ 0$ if no spouse) } \\
\hline & & \multicolumn{5}{|c|}{ Average } & \multicolumn{4}{|c|}{ Greater than zero } \\
\hline $\begin{array}{c}\text { Group } 1 \\
\text { DI/SSI beneficiaries }\end{array}$ & $\begin{array}{c}\text { Group } 2 \\
\text { Non-DI/SSI beneficiaries }\end{array}$ & Group 1 & Group 2 & $p$-val & $\begin{array}{c}\text { Group 2 } \\
\text { reweighted }\end{array}$ & $p$-val & Group 1 & Group $2 p$-val & $\begin{array}{c}\text { Group 2 } \\
\text { reweighted }\end{array}$ & $p$-val \\
\hline With mental illness diagnosis** & Never applied for DI/SSI, with mental illness* & $\$ 9,446$ & $\$ 17,691$ & 0.008 & $\$ 10,559$ & 0.729 & $23.3 \%$ & $38.9 \% \quad 0.006$ & $24.3 \%$ & 0.864 \\
\hline With mental illness diagnosis** & Application rejected/uncertain, with mental illness* & $\$ 9,446$ & $\$ 13,929$ & 0.305 & $\$ 12,670$ & 0.542 & $23.3 \%$ & $36.3 \% \quad 0.103$ & $30.0 \%$ & 0.474 \\
\hline Without mental illness diagnosis** & Never applied for DI/SSI \& no mental illness* & $\$ 14,968$ & $\$ 24,397$ & 0.000 & $\$ 16,305$ & 0.521 & $35.3 \%$ & $48.2 \% \quad 0.000$ & $36.4 \%$ & 0.767 \\
\hline \multirow[t]{3}{*}{ Without mental illness diagnosis** } & Application rejected/uncertain \& no mental illness* & $\$ 14,968$ & $\$ 14,539$ & 0.921 & $\$ 12,938$ & 0.575 & $35.3 \%$ & $36.8 \% \quad 0.799$ & $40.3 \%$ & 0.532 \\
\hline & & \multicolumn{9}{|c|}{ Household earnings per person } \\
\hline & & \multicolumn{5}{|c|}{ Average } & \multicolumn{4}{|c|}{ Greater than zero } \\
\hline $\begin{array}{c}\text { Group } 1 \\
\text { DI/SSI beneficiaries }\end{array}$ & $\begin{array}{c}\text { Group } 2 \\
\text { Non-DI/SSI beneficiaries }\end{array}$ & Group 1 & Group 2 & $p$-val & $\begin{array}{c}\text { Group } 2 \\
\text { reweighted }\end{array}$ & $p$-val & Group 1 & Group $2 p$-val & $\begin{array}{c}\text { Group 2 } \\
\text { reweighted }\end{array}$ & $p$-val \\
\hline With mental illness diagnosis** & Never applied for DI/SSI, with mental illness* & $\$ 5,190$ & $\$ 24,159$ & 0.000 & $\$ 12,637$ & 0.000 & $30.0 \%$ & $70.5 \% \quad 0.000$ & $49.2 \%$ & 0.004 \\
\hline With mental illness diagnosis** & Application rejected/uncertain, with mental illness* & $\$ 5,190$ & $\$ 14,529$ & 0.000 & $\$ 13,115$ & 0.009 & $30.0 \%$ & $62.2 \% \quad 0.000$ & $59.6 \%$ & 0.003 \\
\hline Without mental illness diagnosis** & Never applied for DI/SSI \& no mental illness* & $\$ 11,181$ & $\$ 33,740$ & 0.000 & $\$ 17,874$ & 0.000 & $47.6 \%$ & $80.4 \% \quad 0.000$ & $58.6 \%$ & 0.008 \\
\hline Without mental illness diagnosis** & Application rejected/uncertain \& no mental illness* & $\$ 11,181$ & $\$ 20,885$ & 0.000 & $\$ 16,176$ & 0.047 & $47.6 \%$ & $79.5 \% \quad 0.000$ & $68.8 \%$ & 0.006 \\
\hline
\end{tabular}


Table 6: Household wealth per person among DI/SSI beneficiaries compared with non-beneficiaries

\begin{tabular}{|c|c|c|c|c|c|c|c|c|c|c|c|}
\hline \multirow[b]{3}{*}{$\begin{array}{c}\text { Group 1 } \\
\text { DI/SSI beneficiaries }\end{array}$} & \multirow[b]{3}{*}{$\begin{array}{c}\text { Group } 2 \\
\text { Non-DI/SSI beneficiaries }\end{array}$} & \multicolumn{10}{|c|}{ Net housing wealth (primary residence) per person } \\
\hline & & \multicolumn{5}{|c|}{ Average } & \multicolumn{5}{|c|}{ Greater than zero } \\
\hline & & Group 1 & Group 2 & $p$-val & $\begin{array}{l}\text { Group 2 } \\
\text { reweighted }\end{array}$ & $p$-val & Group 1 & Group 2 & $p$-val & $\begin{array}{c}\text { Group 2 } \\
\text { reweighted }\end{array}$ & $p$-val \\
\hline With mental illness diagnosis** & Never applied for DI/SSI, with mental illness* & $\$ 21,978$ & $\$ 55,382$ & 0.000 & $\$ 48,458$ & 0.001 & $50.6 \%$ & $74.6 \%$ & 0.000 & $62.6 \%$ & 0.095 \\
\hline With mental illness diagnosis** & Application rejected/uncertain, with mental illness* & $\$ 21,978$ & $\$ 23,920$ & 0.717 & $\$ 26,688$ & 0.531 & $50.6 \%$ & $60.9 \%$ & 0.225 & $59.4 \%$ & 0.399 \\
\hline Without mental illness diagnosis** & Never applied for DI/SSI \& no mental illness* & $\$ 41,191$ & $\$ 71,156$ & 0.000 & $\$ 46,430$ & 0.317 & $74.5 \%$ & $82.2 \%$ & 0.013 & $69.5 \%$ & 0.182 \\
\hline \multirow[t]{3}{*}{ Without mental illness diagnosis** } & Application rejected/uncertain \& no mental illness* & $\$ 41,191$ & $\$ 32,902$ & 0.155 & $\$ 30,806$ & 0.085 & $74.5 \%$ & $69.7 \%$ & 0.375 & $77.0 \%$ & 0.678 \\
\hline & & \multicolumn{10}{|c|}{ Net non-housing wealth per person } \\
\hline & & \multicolumn{5}{|c|}{ Average } & \multicolumn{5}{|c|}{ Greater than zero } \\
\hline $\begin{array}{c}\text { Group } 1 \\
\text { DI/SSI beneficiaries }\end{array}$ & $\begin{array}{c}\text { Group } 2 \\
\text { Non-DI/SSI beneficiaries }\end{array}$ & Group 1 & Group 2 & $p$-val & $\begin{array}{l}\text { Group 2 } \\
\text { reweighted }\end{array}$ & $p$-val & Group 1 & Group 2 & $p$-val & $\begin{array}{c}\text { Group 2 } \\
\text { reweighted }\end{array}$ & $p$-val \\
\hline With mental illness diagnosis** & Never applied for DI/SSI, with mental illness* & $\$ 57,815$ & $\$ 133,632$ & 0.002 & $\$ 97,595$ & 0.153 & $72.9 \%$ & $84.2 \%$ & 0.044 & $68.6 \%$ & 0.504 \\
\hline With mental illness diagnosis** & Application rejected/uncertain, with mental illness* & $\$ 57,815$ & $\$ 31,840$ & 0.194 & $\$ 43,517$ & 0.589 & $72.9 \%$ & $75.0 \%$ & 0.775 & $69.7 \%$ & 0.742 \\
\hline Without mental illness diagnosis** & Never applied for DI/SSI \& no mental illness* & $\$ 77,253$ & $\$ 202,097$ & 0.000 & $\$ 111,772$ & 0.103 & $85.1 \%$ & $91.4 \%$ & 0.006 & $77.1 \%$ & 0.010 \\
\hline Without mental illness diagnosis** & Application rejected/uncertain \& no mental illness* & $\$ 77,253$ & $\$ 34,964$ & 0.018 & $\$ 37,263$ & 0.060 & $85.1 \%$ & $82.8 \%$ & 0.596 & $87.8 \%$ & 0.571 \\
\hline
\end{tabular}

*Primary or secondary mental illness diagnosis identified from administrative data (DI/SSI) or previously diagnosed with psychiatric problems or CESD 8 Score $\geq 5$.

**Identified using administrative data as a primary or secondary diagnosis.

$p$-val corresponds to the null hypothesis that the statistic in column Group 1 equals Group 2 (or Group 1 equals Group 2 reweighted) for a given row.

Net housing wealth equals the value of the primary residence (only) less related mortgages and home loans.

Net financial wealth equals the sum of stocks, mutual funds, trusts; checking, savings, and money market accounts; CDs gov't savings bonds \& T-Bills; and other savings,

minus other debt (e.g., credit card, medical debt).

Net non-housing wealth equals net financial wealth plus net value of non-primary residence, net value of vehicles, net value of businesses, and net value of IRA.

Source: Authors' calculations using the HRS linked with SSA administrative data. 
Table 7: Self-reported health insurance status among DI/SSI beneficiaries compared with non-beneficiaries

\begin{tabular}{|c|c|c|c|c|c|}
\hline \multirow{3}{*}{$\begin{array}{c}\text { Group } 1 \\
\text { DI/SSI beneficiaries }\end{array}$} & \multirow{3}{*}{$\begin{array}{c}\text { Group } 2 \\
\text { Non-DI/SSI beneficiaries }\end{array}$} & \multicolumn{4}{|c|}{ Insured } \\
\hline & & Group 1 & Group $2 p$-val & Group 2 & $p$-val \\
\hline & & & & reweighted & \\
\hline With mental illness diagnosis** & Never applied for DI/SSI, with mental illness* & $90.5 \%$ & $66.9 \% \quad 0.000$ & $73.5 \%$ & 0.000 \\
\hline With mental illness diagnosis** & Application rejected/uncertain, with mental illness* & $90.5 \%$ & $53.1 \% \quad 0.000$ & $49.8 \%$ & 0.000 \\
\hline Without mental illness diagnosis ${ }^{* *}$ & Never applied for DI/SSI \& no mental illness* & $85.7 \%$ & $69.6 \% \quad 0.000$ & $63.5 \%$ & 0.000 \\
\hline Without mental illness diagnosis** & Application rejected/uncertain \& no mental illness* & $85.7 \%$ & $59.3 \% \quad 0.000$ & $56.0 \%$ & 0.000 \\
\hline
\end{tabular}


Table A1: Median income and wealth of DI/SSI beneficiaries compared with non-beneficiaries

\begin{tabular}{|c|c|c|c|c|c|c|c|c|c|c|}
\hline \multirow[b]{2}{*}{$\begin{array}{c}\text { Group } 1 \\
\text { DI/SSI beneficiaries }\end{array}$} & \multirow[b]{2}{*}{$\begin{array}{c}\text { Group } 2 \\
\text { Non-DI/SSI beneficiaries }\end{array}$} & \multicolumn{3}{|c|}{ Household income per person } & \multicolumn{3}{|c|}{ Own earnings } & \multicolumn{3}{|c|}{ Spouse earnings } \\
\hline & & Group 1 & Group 2 & $\begin{array}{c}\text { Group } 2 \\
\text { reweighted }\end{array}$ & Group 1 & Group 2 & $\begin{array}{l}\text { Group } 2 \\
\text { reweighted }\end{array}$ & Group 1 & Group 2 & $\begin{array}{l}\text { Group } 2 \\
\text { reweighted }\end{array}$ \\
\hline With mental illness diagnosis** & Never applied for DI/SSI, with mental illness* & $\$ 12,094$ & $\$ 30,603$ & $\$ 19,327$ & $\$ 0$ & $\$ 8,004$ & $\$ 0$ & $\$ 0$ & $\$ 0$ & $\$ 0$ \\
\hline With mental illness diagnosis** & Application rejected/uncertain, with mental illness* & $\$ 12,094$ & $\$ 17,250$ & $\$ 15,787$ & $\$ 0$ & $\$ 0$ & $\$ 0$ & $\$ 0$ & $\$ 0$ & $\$ 0$ \\
\hline Without mental illness diagnosis** & Never applied for DI/SSI \& no mental illness* & $\$ 20,269$ & $\$ 41,297$ & $\$ 24,150$ & $\$ 0$ & $\$ 24,840$ & $\$ 0$ & $\$ 0$ & $\$ 0$ & $\$ 0$ \\
\hline Without mental illness diagnosis** & Application rejected/uncertain \& no mental illness* & $\$ 20,269$ & $\$ 26,220$ & $\$ 23,460$ & $\$ 0$ & $\$ 13,800$ & $\$ 5,520$ & $\$ 0$ & $\$ 0$ & $\$ 0$ \\
\hline & & \multicolumn{3}{|c|}{ Household earnings per person } & \multicolumn{3}{|c|}{ Net housing wealth per person } & \multicolumn{3}{|c|}{ Net non-housing wealth per person } \\
\hline $\begin{array}{c}\text { Group } 1 \\
\text { DI/SSI beneficiaries } \\
\end{array}$ & $\begin{array}{c}\text { Group } 2 \\
\text { Non-DI/SSI beneficiaries } \\
\end{array}$ & Group 1 & Group 2 & $\begin{array}{c}\text { Group 2 } \\
\text { reweighted }\end{array}$ & Group 1 & Group 2 & $\begin{array}{c}\text { Group 2 } \\
\text { reweighted }\end{array}$ & Group 1 & Group 2 & $\begin{array}{c}\text { Group } 2 \\
\text { reweighted }\end{array}$ \\
\hline With mental illness diagnosis** & Never applied for DI/SSI, with mental illness* & $\$ 0$ & $\$ 16,836$ & $\$ 0$ & $\$ 345$ & $\$ 35,880$ & $\$ 17,940$ & $\$ 2,484$ & $\$ 24,219$ & $\$ 4,554$ \\
\hline With mental illness diagnosis** & Application rejected/uncertain, with mental illness* & $\$ 0$ & $\$ 5,520$ & $\$ 3,864$ & $\$ 345$ & $\$ 17,250$ & $\$ 20,700$ & $\$ 2,484$ & $\$ 2,070$ & $\$ 1,518$ \\
\hline Without mental illness diagnosis** & Never applied for DI/SSI \& no mental illness* & $\$ 0$ & $\$ 26,220$ & $\$ 8,280$ & $\$ 27,600$ & $\$ 48,300$ & $\$ 25,530$ & $\$ 8,901$ & $\$ 49,680$ & $\$ 11,040$ \\
\hline Without mental illness diagnosis** & Application rejected/uncertain \& no mental illness* & $\$ 0$ & $\$ 16,560$ & $\$ 13,800$ & $\$ 27,600$ & $\$ 20,700$ & $\$ 15,870$ & $\$ 8,901$ & $\$ 10,350$ & $\$ 6,900$ \\
\hline
\end{tabular}

*Primary or secondary mental illness diagnosis identified from administrative data (DI/SSI) or previously diagnosed with psychiatric problems or CESD 8 Score $\geq 5$.

**Identified using administrative data as a primary or secondary diagnosis.

Source: Authors' calculations using the HRS linked with SSA administrative data. 